\title{
Rumusan Alternatif Strategi Pemasaran Olahan Pangan Kue Nopia di Desa Pakunden Kecamatan Banyumas Kabupaten Banyumas
}

\section{Formulation of Alternative Marketing Strategies for Processed Nopia in Pakunden Village, Banyumas District, Banyumas Regency}

\author{
Novi Dwi Ardani ${ }^{1}$, Pujiati Utami ${ }^{2}$, Dumasari ${ }^{3}$, Watemin ${ }^{4}$ \\ ${ }^{1,2,3,4}$ Program Studi Agribisnis Fakultas Pertanian dan Perikanan, Universitas Muhammadiyah Purwokerto
}

\section{ARTICLE INFO \\ Article history: \\ DOI: \\ $\underline{10.30595 / p s p f s . v 2 i .210}$}

Submitted:

July 29, 2021

Accepted:

Sept 10, 2021

Published:

Nov 10, 2021

Keywords:

Strategy, Marketing, Nopia

\begin{abstract}
This study aimed to determine the formulation of an alternative marketing strategy for processed nopia cakes in Pakunden Village, Banyumas District, Banyumas Regency. The research was conducted in February March 2021 in Pakunden Village, Banyumas District, Banyumas Regency. The number of samples in this study was 26 respondents of nopia maker. The study results stated that the formulation of an alternative marketing strategy for nopia cakes in Pakunden Village, Banyumas District, Banyumas Regency, was to increase the sales production process by maintaining the quality and price of competitors, mastering marketing areas and new customers, take advantage of existing technology to promote it more broadly, expand the place of manufacture and open outlets so that consumers are more familiar with them, has many taste innovations in nopia, and it adds to the workforce in the nopia cakes.
\end{abstract}

This work is licensed under a Creative Commons Attribution 4.0 International License.

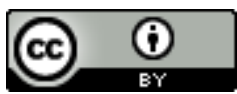

Corresponding Author:

Novi Dwi Ardani

Program Studi Agribisnis Fakultas Pertanian dan Perikanan

Universitas Muhammadiyah Purwokerto

Email: agribisnisump2020@gmail.com

\section{PENDAHULUAN}

Sistem agribisnis terdiri dari subsistem input, usahatani (pertanian), sistem output, pemasaran dan penunjang. Dengan demikian pembangunan agroindustri tidak dapat dilepaskan dari pembangunan agribisnis secara keseluruhan. Pembangunan agroindustri akan dapat meningkatkan produksi, harga hasil pertanian, pendapatan petani, serta dapat menghasilkan nilai tambah hasil pertanian (Masyhuri, 1994).

Salah satu strategi yang dapat ditempuh untuk mengembangkan perekonomian daerah adalah melalui pengembangan agribisnis yang berwawasan kerakyatan. Secara konsepsional sistem agribisnis dapat diartikan sebagai semua aktifitas, mulai dari pengadaan dan penyaluran sarana produksi sampai dengan pemasaran produk-produk yang dihasilkan oleh usahatani yang saling terkait satu sama lainya. Peranan agribisnis dalam peningkatan pendapatan petani sangat besar, karena didalam sistem agribisnis diutamakan keterpaduan antara empat subsistem yakni subsistem pengadaan dan penyaluran (Ismini, 2010).

Ketika produsen dalam memasarkan produknya sering kali mendapatkan kendala, kemudian pada strategi bauran pemasaran adanya proses pertukaran dan pengembangan hubungan dengan konsumen dengan cara mengamati kebutuhan dan keinginan konsumen yang dilanjutkan dengan mengembangkan suatu produk 
(product) yang menjadikan konsumen puas dengan produk tersebut, dengan menawarkan harga (price) pada produk tersebut, tentu mendistribusikannya supaya terdapat tempat (place) yang menjadikannya pasar bagi produk yang bersangkutan serta dilakukannya kegiatan promosi (promotion) (Kotler, 2005).

Di pedesaan, saat ini banyak masyarakat yang mengolah dan memanfaatkan hasil pertaniannya. Karena ingin meningkatkan pendapatan ekonominya. Sehingga mereka pun bisa menjadi seorang pengusaha di desanya. Dalam mencapai keberhasilan tentu banyak hal yang harus di hadapi supaya tetap berkembang usahanya.

Dari hasil observasi wawancara, usaha kue nopia berdiri sejak tahun 1987 dan dijalankannya secara turun temurun. Awalnya hanya memiliki satu varian rasa saja yakni rasa bawang merah goreng atau lebih dikenal dengan rasa brambang goreng. Seiring permintaan konsumen sehingga sekarang kue nopia memiliki banyak varian rasa, ada rasa coklat, gula merah, pandan, dan durian. Di Kecamatan Banyumas tepatnya di Desa Pakunden merupakan Desa yang banyak memproduksi kue nopia. Pada kondisi usaha kue nopia di Desa Pakunden yang berkembang mengakibatkan adanya persaingan yang semakin luas sehingga strategi pemasaran perlu dilakukan oleh produsen kue nopia supaya usahanya tetap berkembang.

Kue nopia yang berasal dari Desa Pakunden memiliki rasa yang khas, dengan bentuk yang bulat seperti layaknya kue bakpia Yogyakarta dan rasanya yang khas tersebut menjadikan kue nopia dikenal sebagai makanan khas Banyumas. Harga kue nopia dengan berat 3,5 ons seharga Rp 9.000 dan harga kue nopia per Kg seharga Rp 25.000. Biaya yang dikeluarkan untuk memproduksi kue nopia meliputi biaya tenaga kerja, biaya bahan baku, kemasan, dan biaya bahan bakar. Kue nopia sudah di pasarkan di beberapa wilayah yaitu : di tiap toko-toko yang ada di Kecamatan Banyumas, Sokaraja, Kroya, dan Jogja. daya simpan kue nopia relatif lama bisa mencapai 3 bulan.

Awalnya produk kue nopia ini dipromosikan kepada masyarakat lokal Banyumas saja, pada awalnya kue nopia belum mempunyai label nama pada kemasan plastik kue nopia. Kemudiam kue nopia dipromosikan melalui youtube, dan dititipkan di toko terdekat. Kemudian dengan berkembangnya kue nopia hingga bisa menyebar luas ke berbagai daerah. Sehingga kue nopia mempunyai label pada kemasan, hingga kue nopia bisa terkenal sebagai makanan khas Banyumas.

\section{METODE PENELITIAN}

Penelitian ini dilaksanakan di Desa Pakunden, Kecamatan Banyumas, Kabupaten Banyumas, Jawa Tengah. Pemilihan lokasi penelitian dilaksanakan secara sengaja, karena di Desa Pakunden terdapat pengusaha olahan kue nopia dalam jumlah yang banyak. Metode yang digunakan saat penelitian adalah deskriptif. Metode deskriptif merupakan metode yang memusatkan diri pada pemecahan-pemecahan masalah yang ada pada masa sekarang. Pada masalah-masalah yang aktual dimaksudkan untuk memahami masalah-masalah manusia dalam konteks sosial dalam menciptakan gambaran menyeluruh dan kompleks yang di sajikan dengan melaporkan pandangan terperinci dari para sumber informasi dan data yang dikumpulkan mula-mula disusun, dijelaskan kemudian dianalisa (Surakhmad 1994).

Sampel penelitian merupakan produsen kue nopia yang terdapat di Desa Pakunden, Kecamatan Banyumas, Kabupaten Banyumas. Pengambilan sampel penelitian ini menggunkan tenik sensus. Teknik sensus merupakan teknik pengumpulan sampel bila semua anggota populasi digunakan sebagai sampel (Sugiyono 2009). Diketahui populasi produsen kue nopia di Desa Pakunden, Kecamatan Banyumas, sebanyak 26 orang, sehingga total responden pada penelitian ini sebanyak 26 orang.

Untuk mengetahui strategi pemasaran digunakan analisis matrik SWOT digunakan sebagai identifikasi berbagai faktor secara sistematis untuk mengetahui pada situasi dan kondisi sebuah usaha dan sebagai masukan strategi pemasaran yang dapat diterapkan oleh produsen kue nopia di Desa Pakunden, Kecamapan Banyumas, Kabupaten Banyumas.

\section{HASIL DAN PEMBAHASAN}

Faktor kekuatan, kelemahan, peluang dan ancaman pada aktivitas pemasaran olahan pangan kue nopia di Desa Pakunden Kecamatan Banyumas Kabupaten Banyumas, sebagai berikut:

\section{Kekuatan}

a. Produk kue nopia dikemas menggunakan plastik yang ada labelnya sehingga konsumen merasa puas dengan produknya, sehingga produk kue nopia lebih unggul dibandingkan yang lain. Daya simpan kue nopia relative lama mencapai 3 bulan.

b. Harga kue nopia terjangkau untuk masyarakat sehingga konsumen puas dengan harga yang diterapkan oleh produsen.

c. Pembuatan kue nopia sangat strategis karena sudah masuk di Kotanya, dekat dengan jalan raya dan juga dekat dengan toko dan swalayan untuk membeli bahan baku kue nopia.

d. Promosi yang dilaksanakan sudah mencakup seluruh sasaran pasar usaha kue nopia, dan memanfaatkan kemajuan teknologi untuk memasarkan produk kue nopia. Terkadang ada diskon khusus untuk pelanggan setia produk kue nopia dengan membeli jumlah yang banyak. 
2. Kelemahan

a. Proses pemanggangan kue nopia terkadang ada yang gosong dan kue nopia hanya berbentuk bulat, kemasan kue nopia menggunakan plastik yang sudah disediakan produsen.

b. Harga bahan baku kue nopia seperti gula merah tidak stabil, maka produsen membelinya diluar Kecamatan Banyumas dengan tujuan mencari harga yang lebih murah. Sehingga harga kue nopia tidak dinaikan pada saat harga bahan baku kue nopia naik.

c. Tempat pembuatan kue nopia masih sempit karena masih gabung dengan rumah produsen kue nopia dan masih gabung dengan dapur rumah.

d. Untuk promosi kue nopia masih sangat kurang memanfaatkan teknologi yang ada karena rata - rata produsen kue nopia hanya menggunakan hp hanya untuk keperluan seperti menerima telefon dan menerima pesan sms.

3. Peluang

a. Produk kue nopia merupakan makanan khas dari Banyumas, dengan berjalannya waktu maka kue nopia menjadi salah satu produk unggulan Daerah dan seiring permintaan kue nopia dari konsumen cukup tinggi. Untuk ketersediaan bahan baku pembuatan kue nopia cukup.

b. Harga kue nopia relative murah sehingga konsumen menerima harga kue nopia yang ditentukan oleh produsen.

c. Produsen kue nopia sudah memiliki outlet di Desa Pakunden Kecamatan Banyumas Kabupaten Banyumas sehingga konsumen mudah untuk membelinya, ada juga yang dititipkan di toko oleh-oleh, swalayan dan toko-toko kecil seperti warung.

d. Promosi kue nopia sudah sampai luar Daerah, karena produsen kue nopia kerjasama dengan perusahaan Bogasari terkait dengan persediaan bahan baku pembuatan kue nopia seperti tepung terigu.

4. Ancaman

a. Produk kue nopia mempunyai banyak pesaing dari Daerah lain, maka kualitas pada produk kue nopia menurun dapat mengurangi minat pembeli kue nopia sehingga pelanggan bisa berkurang. Karena konsumen selalu melihat kemasan produk kue nopia saat membelinya.

b. Harga kue nopia jika dinaikan ketika bahan baku pembuatan kue nopia naik maka konsumen segera mencari produk kue nopia dari Daerah lain, karena konsumen mencari harga yang murah. Ketika konsumen membeli produk kue nopia dengan menawar harga yang sudah ditentukan produsen maka usaha akan merugi.

c. Tenaga kerja ditempat pembuatan kue nopia masih sedikit karena tempat pembuatannya masih gabung dengan rumah produsen.

d. Promosi kue nopia masih kurang ketika memanfaatkan teknologi untuk memasarkan produk kue nopia.

Strategi pemasaran yang ada pada usaha kue nopia di Desa Pakunden Kecamatan Banyumas. Perumusan strategi ini menggunakan analisis SWOT. Pada analisis SWOT merupakan tahapan percocokan untuk menghasilkan alternatif strategi yang cocok dengan melihat pada aspek kekuatan, kelemahan, peluang dan ancaman, yang diidentifikasi menggunakan matrik IFAS dan EFAS. Hasil SWOT dalam menentukan alternative strategi pemasran yang telah dilakukan oleh produsen kue nopia di Desa Pakunden Kecamtan Banyumas.

1. Strategi $S O$

a. Meningkatkan proses produksi penjualan dengan mempertahankan kualitas dan harga pesaing. Pada strategi ini dilakukan untuk memuaskan konsumen saat membelinya supaya tidak kecewa dan tidak berpindah ke pesaing kue nopia dari Desa lainya. Selalu memenuhi banyaknya permintaan kue nopia dari konsumen, dengan didukungnya bahan baku yang mudah didapatkannya dengan harga yang standar.

b. Menguasai Daerah pemasaran dan pelanggan baru, strategi ini dilakukan supaya selalu mempunyai pelanggan baru dengan cara memasarkan produk diberbagi Daerah supaya lebih dikenal masyarakat. Dan berusaha meningkatkan kerja sama dengan toko oleh-oleh, swalayan, dan toko-toko kecil seperti warung. Cara yang harus dilaksanakan yaitu ada beberapa syarat yang harus bisa terpenuhi supaya kue nopia bisa dititipkan. Seperti harus ada label pada kemasan kue nopia dari dinas kesehatan, sertifikat halal, tanggal kadaluarsa dan sejenisnya.

\section{Strategi $W O$}

a. Memanfaatkan teknologi yang ada supaya promosi lebih luas. Strategi ini dilaksanakan supaya kue nopia lebih dikenal ke setiap Daerah, cara yang dapat dilakukan yaitu dengan cara promosi melalui sosial media seperti fecebook, instagram, youtube, whatsaap dan juga bisa dilakukan promosi menggunakan radio, surat kabar, brosur, ataupun secara langsung tatap muka.

b. Memperluas tempat pembuatan dan membuka outlet supaya lebih di kenal konsumen. Strategi ini dilaksanakan supaya saat proses pembuatan kue nopia lebih mudah dan ketika konsumen membelinya dengan cara datang ke tempat pembuatannya secara langsung tidak sempit. Dan membuka outlet untuk 
mengembangkan usaha kue nopia supaya semakin maju, dan memudahkan konsumen untuk membelinya.

\section{Strategi WT}

a. Mempunyai banyak inovasi rasa pada produk kue nopia, strategi ini dilakukan supaya konsumen tidak bosan dengan citra rasa sehingga produsen memperbanyak inovasi rasa pada kue nopia. Menambah tenaga kerja, strategi ini dilakukan dengan cara menambah tenaga kerja supaya saat permintaan konsumen tinggi produsen tidak terburu-buru proses pembuatannya, misalnya seperti hari lebaran biasanya permintaan konsumen banyak karena biasanya dibawa untuk oleh-oleh.

\section{KESIMPULAN}

Hasil alternaif pada rumusan strategi pemasaran kue nopia di Desa Pakunden Kecamatan Banyumas Kabupaten Banyumas menggunakan analisis SWOT yaitu meningkatkan proses produksi penjualan dengan mempertahankan kualitas dan harga pesaing, menguasai daerah pemasaran dan pelanggan baru. memanfaatkan teknologi yang ada supaya mempromosikannya lebih luas. memperluas tempat pembuatan dan membuka outlet supaya lebih di kenal konsumen. mempunyai banyak inovasi rasa pada kue nopia, dan menambah tenaga kerja di tempat pembuatan kue nopia.

\section{DAFTAR PUSTAKA}

Badan Pusat Statistik. (2019). Kecamatan Banyumas Dalam Angka 2019. Banyumas.

Kotler Philip. (2002). Manajemen Pemasaran Analisis, Perencanaan, Implementasi dan Pengendalian. Erlangga. Jakarta.

Kotler. (2005). Manajemen Pemasaran jilid 2. Erlangga. Jakarta.

Masyhuri. 1994. Pembangunan Agribisnis dalam Era Globalisasi. Fakultas Pertanian UGM. Yogyakarta.

Maulidah. (2012). Pengantar Manajemen Agribisnis. Universitas Brawijaya Press. Malang. Sugiyono. (2009). Metode Penelitian Kuantitatif,
Bandung.

Surakhmad, Winarno. (1994). Pengantar Penelitian Ilmiah, Dasar, Metode dan Teknik. Bandung.

Swastha Basu dan T. Handoko Hani. (1997). Manajemen Pemasaran (Analisis Perilaku Konsumen). BPFE. Yogyakarta. 